\title{
Anthrovision
}

Vaneasa Online Journal

Vol. $7.1 \mid 2019$

Aesthetic Encounters

\section{Value, Correspondence, and Form: Recalibrating Scales for a Contemporary Anthropology of Art (Epilogue)}

Jonas Tinius

\section{(2) OpenEdition \\ Journals}

Electronic version

URL: http://journals.openedition.org/anthrovision/4356

DOI: 10.4000/anthrovision.4356

ISSN: 2198-6754

Publisher

VANEASA - Visual Anthropology Network of European Association of Social Anthropologists

\section{Electronic reference}

Jonas Tinius, «Value, Correspondence, and Form: Recalibrating Scales for a Contemporary Anthropology of Art (Epilogue) », Anthrovision [Online], Vol. 7.1 | 2019, Online since 11 March 2020,

connection on 13 November 2020. URL : http://journals.openedition.org/anthrovision/4356 ; DOI https://doi.org/10.4000/anthrovision.4356

This text was automatically generated on 13 November 2020.

(c) Anthrovision 


\section{Value, Correspondence, and Form: Recalibrating Scales for a Contemporary Anthropology of Art (Epilogue)}

Jonas Tinius

\section{Emerging Anthropologies of Art}

1 In the introduction to their influential volume The Traffic in Culture (1995), George Marcus and Fred Myers note that 'art has come to occupy a space long associated with anthropology, becoming one of the main sites for tracking, representing, and performing the effects of difference in contemporary life' (Marcus and Myers 1995: 1). Published more than twenty years ago, this statement still rings true, but with some qualifications. Marcus and Myers' concern for a recast perspective on 'Western art worlds' (Marcus and Myers 1995) has laid the foundations for a set of different perspectives in the anthropology of art and visual cultures that - at once - seem to have gone a long way while making steps backwards since then. In this afterword, I try to witness some of these short, and a few longer passages that have been made since then, reviewing both a broader literature related to the theme of this special issue and convergent strands of inquiry and trajectories evoked and addressed by the papers in this publication.

2 It has been widely attested that the global circulation, export, and imposition of particular ethnocentric (often a short-hand for Euro-American) concepts of art, aesthetic judgment, and forms of artistic exhibiting have simultaneously created a homogenous global phenomenon - a 'metropolitan conversation' (Schneider 2017: 1) while at the same time incorporating cyclically a changing set of geographicallyspecific and often essentialist cultural, regional, or even continental styles and art fields (see Schild, this issue). Museums, art fields, and curatorial agents articulate 
national narratives and digest troubling cosmopolitan challenges against them (see e.g. Levitt 2015; Tinius and Macdonald 2020; Tinius and Zinnenburg 2020). This simultaneous export and incorporation, expansion and centralization extends to forms of artistic communication and distribution, for example through particular exhibition formats (Dimitrakaki 2012), but also means and materialities and rejections thereof (see Bishop 2012 and Fillitz, this issue). The naïve celebration of an exchange of perspectives between artistic form in international, or even 'nomadic' biennales, such as Manifesta, has not least become subject to their own critique (Kompatsiaris 2017). Equally, the proliferation of an entire cross-pollinating and -sustaining art-philosophy-theory nexus on precariousness, creativity, and the variously exoticized or pathologized agency of the expat artist jet-set or the equally ambivalent ubiquity of the projectbased, self-fashioning, and independent curator of contemporary (art) worlds has ceased to surprise or provoke (witness e.g. Balzer 2015; Avanessian 2017). Contemporary artists and artistic styles have been entangled in the same mobile and global 'scapes' that Arjun Appadurai conjured previously as 'constitutive feature[s] of modern subjectivity' (2001: 3); and they have turned these into means of theoretical production. The cogency of reflexive contemporary art, in that sense, can therefore no longer be regarded merely in what it 'offers' to anthropology, but in its unfazed incorporation of anthropological concerns for the diverse relational and scalar entanglements of the global and local. In some instances, as in the exhibitionexperiment Gifts to Soviet Leaders that nourished Nikolai Ssorin-Chaikov's research manifesto for an ethnographic conceptualism (2013), this has in turn become a source for methodological and theoretical propositions.

3 It is evident, thus, that the rapid digital capacities for the distribution of images, money, and data and the inflation of cheap global travel produce ambivalent effects on the possible encounters between global and local art canons. The former has, of course, already been attested as constitutive of the infrastructural undergirding of globalization (see Kearney 1995). Aesthetic ideas, fashionable styles of artistic production, as well as the curatorial discourses that facilitate them, already travel from, say, Paris to Venice to Lubumbashi and Hong Kong within a month. In spite of this, there are a great number of profoundly coherent trajectories within the proclaimed horizontal and hybrid connectivity of these flows, which have not rescinded their autonomous thought and practice.

4 So what concerns does this raise for a contemporary anthropology of art and aesthetics that is attentive to the politics of moving and the apparent unsettlement of its categories and fields of study? The editor of this special issue has identified as a theme 'anthropology's interactions with visual arts, literature, film, and design within the framework of the multiple meanings these arts have taken nowadays with their unprecedented circulations and receptions at a global scale' (Fillitz, introduction, this issue).

5 For Fillitz, anthropological scholarship on this circulation and reception since the early 1990s accounted for these phenomena no longer by reference to 'the former universalistic pretension of European modernism's canons in the various arts,' but with a growing consciousness about 'geospatial [and, one might add, geopolitical] diversity' (Fillitz, introduction, this issue). He is keenly aware that such transformations did not come about, or produce, an early internet age utopia of frictionless network translation, but crafted old power relations onto this new infrastructure. As Marilyn 
Strathern (1996) already noted in her critique of ANT and its neutralised network metaphor, 'the power of such analytical networks is also their problem: theoretically, they are without limit' (Strathern 1996: 523). The same observation - and the same critique - applies to the study of relations between international art circuits and locally focused projects and institutions.

6 If this is the case, an anthropology of contemporary art and aesthetics, which is itself attuned to a contemporary perspective, that is, one willing to step aside and question its own intrication in the production of the local and global, is in an important position to perform a double move. It acknowledges simultaneously two dimensions. First, that in terms of digital connectivity, technological transformation, logistical intensification, and precarization of professional worlds, we have to catch up with a set of early twenty-first century 'givens' that no longer surprise. Secondly, it begs us to attune to a situation in which this very alteration has both integrated and neutralised, yet not consumed and rendered disjunctive the idiosyncrasies and specifics - the heterogeneity of homogeneity - within fields that may appear to be simply relational, multi-sited, and endlessly circulating (see García Canclini 2014a).

7 An attuned anthropology of the contemporary, which focuses on the tensions of art and aesthetics across scales of glocality, might then benefit from an anachronistic and anatopical positionality and approach. This phrasing borrows from Michel Foucault's notion of the heterotopia (1986) and Giorgio Agamben's figure on the contemporary (2009) as someone at once immersed and at the same time removed from the immensity and density of the present; to be reflexively calibrated to contemporary worlds, then, is to be contemporary and anachronistic, disjointed and at a queer angle to a contemporary condition and position. This position recognizes unevenness as part of the condition of supposed horizontality (see Schneider 2015). The anthropology of markets, collectors, curators, and further agents in this emergent glocal field (see e.g. Fillitz and van der Grijp 2018), where new spheres of valuation and aesthetics emerge, creating new canons as well as resistances, is itself firmly implied in this condition. We are thus in a trans-anthropological phase in which anthropology no longer documents, but constitutes these fields itself (see Oswald and Tinius 2020). This affords a greater reflexivity about the collaborative modalities and theoretical value generated through our scholarship as anthropologists; it also asks for a recalibrated ethnographic awareness of the co-articulation of art and anthropology at all scales of their encounter. The theories we generate and the methods we mobilize are not detached from the 'tools for the production of difference' (Fillitz, introduction to this issue) enacted by the hierarchies of art production at a global level. To return to Marcus and Myers' (1995) introduction which I cited at the outset, we need to look at both art and anthropology, not just one or the other, for 'tracking, representing, and performing the effects of difference in contemporary life' (Marcus and Myers 1995: 1). A recalibrated anachronistic and anatopical anthropology of the contemporary historicizes and contextualizes these tools through which contemporary global art spheres circumscribe the present condition, and renders these a subject of analysis. As such, the ongoing and cumulative historicization and de-localization of artistic production from within the fields themselves become tools of our own analysis. 


\section{Convergent Strands of Inquiry and Trajectories}

8 The articles in this special issue speak from particular places and fields of ethnographic inquiry. Each contribution shows a marked concern for the ways in which the local and the global articulate and constitute each other, not necessarily in the affirmative or the empathic, but also in rejection and reification. But for me there are two sets of distinct analytical trajectories that I want to highlight below. They concern, broadly, the nexus 'institutions, histories, and spheres of valuation' (Thomas Fillitz and Tamara Schild) and 'immersion, correspondence, and form' (Alex Flynn/Lucy Bell and Paolo Favero).

\section{Institutions, Histories, and Spheres of Valuation}

Thomas Fillitz and Tamara Schild provide two accounts of an anatopical and anachronistic anthropology of the contemporary as I propose it above; they are firmly situated in several years-long ethnographic fieldwork - in Paris and Dakar, respectively - but focus on the ways in which the art markets and art institutions of each field demarcate and formulate borders of local, global, African, European, noire, ethnographic, etc. They underline the role of institutions and spheres of valuation, in particular art auction houses and biennales, and the particular geopolitical and geospatial imaginations as well as the historical, and especially art historical, framings that each enact. Their accounts speak of the generation of locations and attention to the multitudes - and the insufficiency of this term - to grasp the aesthetic and economic dimension of form and materiality in artistic production, curation, and collection. This first section addresses also curatorial influence, institutional framing, and the changing ethico-aesthetic realms that certain forms, modes, and categories of art undergo (see also Tinius 2018). Fillitz and Schild also speak of the often-overlooked diachronic trajectories in our research sites, and the contrasting reasons for the emergence of certain styles and unexpected forms - such as painting in the off scene of the Dak'Art Biennale - over time. They furthermore underline the role of institutions, including that of the art market, and parallel narratives for the emergence of comparisons and juxtapositions of artists, artworks, and styles. Schild raises the intriguing issue of the circulation and valuation of categories such as 'ethnographic' or 'anthropological' entirely beyond the professional academic confines of the discipline in universities and museums, addressing the role of individual collectors and their dubious curiosity for 'African' art incorporated into Euro-American collections that so starkly contrasts the footnotes on private collectors in Felwine Sarr and Bénédicte Savoy's restitution report (2018). In what ways do institutions and spheres of valuation create barriers and impasses, not just connections and flows, that variously block, constrain, and control capital and power, form and medium?

Thomas Fillitz draws on long-term fieldwork with the Senegalese Dak'Art Biennale for his article. His principal observation concerns the discrepancy between the official Biennale in Dakar and the sprawling and recognised so-called off, a notion familiar from other event contexts, such as the Avignon festival of performing arts and theatre in France. Fillitz notes that, counter to the assumption that large-scale exhibition events such as this one, the most well-known biennale of contemporary art in Africa, the global arts discourse and its aesthetics has only a limited influence on what happens beyond the official part of the exhibition. In fact, the exhibitions of the 
Dak'Art Off 'offer an image of demarcation from global art discourses and their aesthetic judgements about the most relevant art forms and pressing issues', as he demonstrates. In contradistinction to the official shows, where installation art dominates, the majority of the off features paintings. Fillitz then delves into a discussion of the history of Senegalese post-independence modern art, arguing that an explanation of the choices of media and aesthetics in the off require a greater understanding of this history than the official biennale, whose discourses and choices are predominantly influenced by the respective curatorial teams. (This is not to say that there cannot also be a history and genealogy of the official exhibition, but these offer different trajectories.) Apart from the difference in media, Fillitz also underlines that the kinds of spaces chosen in the Off offer a set of different affordances and principles of production, including the marked absence of curators and links to socioeconomic and political realities that the official biennale barely touches or grasps. The provocative thrust of his argument, however, does not primarily concern the tensions between the Off and the 'In', but the fact that the official biennale discourse does not in fact dictate or influence what is understood as contemporary art in this context, even though it might be the most obvious platform to do, or to be assumed to do so.

11 Most notable in his review of the Dak'Art off genealogy is the influence of Léopold Sédar Senghor about whom, not coincidentally and to blur the distinctions here even further, the last two Dak'Art Biennale editions' curator Simon Njami wrote a biography, C'était Senghor (2006). Founding figure of the 1960 École des Arts du Sénégal, later renamed into École Nationale des Beaux Arts, Senghor facilitated a school that focused on painting and some sculpture. However, as the Senegalese art historian Abdou Sylla (1998: 110) notes, the vast majority of the artists there - eighty percent, to be exact practiced painting. Further, Sylla underlines the social service of the arts and artists coming out of and related to the school, all of which are related to the 'local developments of the late 1970s' (1998), and thus to a history that is to a large degree disconnected from recent contemporary arts biennale discourse. Moreover, even though Senghor's cultural policies and politics of Négritude 'attributed artists the role of important agents for the production of the national cultural discourse' (Fillitz, this issue), artists also sought to liberate themselves from the hegemony of a statist framework.

In his ethnographic forays into various Off sites, Fillitz furthermore evokes another trajectory, which is key to understanding the predominance of certain art forms and styles in the Off, namely that of the Laboratoire Agit'Art. Founded in 1973, the collective reacted to the styles and traditions of the École de Dakar and what they perceived as the school's apolitical stance, instead rejecting state patronage and mobilizing in favour of an artistic activism. The development of the Dak'Art Off, further facilitated by a number of other factors, including a commercial orientation, a focus on urban regeneration, and an absence of overall curatorial figures, leads Fillitz to conclude that while the two fields operate in different trajectories and aesthetic frameworks, they operate in a complementary relationship that helps understand the articulation of styles along a complex scale from the local courtyard to the EuropeanAfrican diaspora superstar curators and the canonisations of contemporary art that comes, for better or worse, and whether they wish it or not, with their practice.

13 The article evokes the much-rehearsed discussion of the effects of the geospatial metaphors of the global and the local, offering a counter-narrative to the assumption 
that the homogenous global circuit has overdetermined the visual and exhibitionary culture of the Dak'Art Off. It also prompts a related ethnographic reflection worthy of further deliberation, namely one regarding the demarcation of the field: where and how does the study of a biennale, or of biennale cultures in the plural begin and end? As so often, it appears that it is neither sufficient to drift along the edges and into the supposed periphery to realize that the generative potential lies there; rather, it takes of the observer a particular step aside in space and in time, to fully understand the coconstitutive demarcations and means of producing internal differentiation within fields such as this.

14 Tamara Schild presents a distinctively different field that intersects uncomfortably with the emic dynamics evoked by the previous analysis. She focuses on the marketing of Ancient African and Oceanic Art at high-end auction houses Sotheby's and Christie's, which account for seventy percent of the total auction market sales volume in these categories. In 2017, their sales volume totaled $€ 58$ million, which, however significant for this segment, amounts to a small percentage in these firms' overall revenues. Schild's focus is not on mere economic facts, though, but focuses on the strategies of auction houses to establish links between modern and contemporary Euro-American art and so-called African and Oceanic art for purposes of marketing. Indeed, she argues that one of the main functions of an increased interest in this historical link catalogues mentioning Western artists and their relation to African and Oceanic arts have apparently multiplied since the beginning of the twenty-first century - is the encompassing of the latter category in the 'modes of presentation typical for modern and contemporary art' (Schild, this special issue). Among a number of different factors, the increase in prices facilitated by marketing and auction house spectacles draws attention to this category of works, rather than their intrinsic materialities or other features of qualitative depth.

Crucial in her analysis is the role of curating and collecting. Not just the selection and presentation of non-European works and their connections to existing market segments conducted by auction houses matters, but also individual 'cross-category collectors' (Schild, this special issue) play a key role. As recounted by Javier Peres, founder of Peres Projects and representative of a "new generation of African art collectors' (Schild, this special issue), his attendance of the ethnographic museum in Berlin led him to appreciate and 'train' his eye for non-European, in particular African, art objects. Besides personal interest and marketing through gallery representations, Schild reviews that other factors such as high-end catalogues and their juxtaposition of 'academic knowledge, photographic techniques, visual "aesthetic" criteria, historicity, and provenance are used in the construction of market values' (Geismar 2001: 36). Her article juxtaposes starkly the two competing Dakar fields of valuation by introducing the agency of market curators and auction houses with their spheres of valuation that extend beyond the discursive into the materialities and individualised narratives that generate cross-continental aesthetics.

16 Yet, there is evidently at play in the processes she describes a profit-oriented encompassment and reification of particular types of art objects; it is indeed not farfetched to ponder to what extent art institutions such as auction houses are not just creating value (both pecuniary and symbolic), but actually co-create entire value spheres and, more significantly, spheres and parameters for the valuation of art. Reposing the question of the trans-anthropological in this context, the role of 
anthropologists and creative refusal on behalf of more critically-minded cross-over scholars and curators merit more attention. How do they effect these spheres and values? What generative effect do art historians have in the re-constellation of art historical proximities that help feature and market art objects previously associated with ethnographic museum collections, rather than glossy catalogues and high-end 'coffee-table' books meant primarily for display. And to what extent are these valuations to be regarded historically and in relation to the dubious and unearthed stories about the unjust acquisition of colonial artefacts? It remains an intriguing tension, here merely noted in passing, how differently provenance research serves a function in the critically-minded scholarship on colonial histories, raising problems and deliberately troubling the circulation and marketing of certain objects, while provenance in another context serves to establish and consolidate value.

\section{Immersion, Correspondence, and Form}

In the second section of my discussion, I focus on the nexus 'immersioncorrespondence-form'. I derive these notions from a review of Alex Flynn and Lucy Bell's as well as Paolo Favero's contributions to this special issue. Their accounts, divergent again in fieldwork setting and subject, share a concern for the generative effects of immersion, both as experience and as method. In the case of Flynn and Bell, immersion casts itself as a problem of social relations and the echo of fieldwork experiences in research method and design. For Favero, immersion is also at once a subject of study and a constitutive ethnographic experience, for example of virtual reality projections and religious icons, whose agency he analyses. Both contributions focus furthermore on forms of reflexivity and recursivity between fields of literary and visual artistic productions on the one hand, and anthropological method and ethnographic theory on the other. They offer us thus a form of counter-narrative to the framing context of global aesthetic flows I somewhat broadly sketched in my introduction, arguing for both extremely close and micro-analyses of social relations in specific sites (be they analogue or digital) and for the generation of new approaches to cultural, literary, and visual artistic production. Their recalibration, then, takes place (in the literal sense of the phrase) and enacts itself through an insistence on the value of the speaking and viewing position and its relational and reflexive qualities and potentials (see also Flynn and Tinius 2015).

This second section additionally addresses the affordances of the particular materialties and immaterialities as well as the ways in which our research design, experience, and theoretical generation can correspond with these. What kinds of influence does the materiality and form of the artistic processes we study have on the way we can relate to these? In what sense do virtual images reveal themselves, how does their agency get mediated to us differently than, say, hand-made books?

In their contribution entitled 'Returning to Form,' Alex Flynn and Lucy Bell draw on fieldwork with cartonera publishers, poets, and activists. Cartonera appeared in the midst of the 2001 economic crisis in Buenos Aires and provided means to outcast residents of the city to produce goods and survive economically. Known as cartoneros, meaning 'cardboarders' or 'waste pickers,' these practitioners combined a collection and recycling of waste with the production and consumption of literature. The production of cheap books bound in cardboard and the very materiality of the books, 
Flynn and Bell argue, was 'deeply embedded in the complex social fabric of the city, incorporating its uneven social strata, from informal street workers to an emerging class of wealthy consumers' (Flynn and Bell, this special issue). In such a way, this hybrid art form echoes already in itself the complexity of urban and economic life. Flynn and Bell seek to find a kind of correspondence between the location, production, and practice of Dulcinéia Catadora, a cartonera publisher based in São Paulo and the anthropological methods of fieldwork and dissemination. They propose, in sum, a corresponding methodology of anthropological research 'that is premised on the relation between social and aesthetic form' (Flynn and Bell, this special issue), focusing on the four forms of operation by which cartonera publishers mediate their practices and materials: exhibitions, workshops, co-editions, and encontros ('gatherings').

Because cartonera publishing, both in form and content, are inextricably linked to the material conditions of their production, Flynn and Bell urge an engagement with these contexts in the same terms. What is more, the publishers and collectors involved in producing these books are, we learn, themselves highly aware of the kinds of economic activities and the politics of recycling they produce - as well as the politics and epistemological value-added through their methods of production (for a comparable context see also Alexander and Sanchez 2018).

Dulcinéia Catadora, the São Paulo cartonera publisher serving as a case study in their contribution, is a markedly material environment. Materials are collected, stored, and bound, reshuffled and handled, offering a translation of material value from one sphere (the street, dirt, rubbish) into quite another (the bookshelf, poetry, literature), though my own sighting of poetry would not necessarily, as the authors also point out, suggest that the subjects of the books are divorced from the harshness of poverty and the street. This offers another question about the possible correspondence not just between form of the books and the design of research, but also the content of both. Flynn and Bell, however, are more interested in the social relations crafted on the materialities and forms of the cartonera publishers, which they compare in a wider ethnographic project with similar practices in Mexico and elsewhere in Brazil.

Beyond their ethnographic descriptions and methodological proposals, the authors intervene in a debate about the relation of 'aesthetics and politics' citing and discussing Jacques Rancière (2004), Néstor García Canclini (2014b), and Caroline Levine (2015). Refreshingly, they are not rehashing the same trodden arguments about these authors, especially about the division of the sensible, but rather seek from them operationalizable moves into a correspondence between social aesthetics and political theorisation of cultural production. In this endeavour, it is Levine (2015) who proposes the most intriguing notion by speaking of practices of reading and literature as potentially radical because of their 'rearrangement' of different configurations of form. This, a crucial element to Flynn and Bell's proposal for a trans-formal approach to ethnography, works across the formal arrangements and correspondences of cultural, artistic, anthropological, social, economic, and political composition.

It is, however, this very trans-formal approach that lends itself to the same critique of a supposedly, possible clean, and endlessly-extensive mediation that I reviewed with regard to ANT in my introduction. How can one transverse these terrains despite their unevenness, both within the field, and across it into the realm of an anthropological methodology and institutionalised Western set-up? In spite of these tensions, their case study complements my discussion of the performativity of value spheres and spheres of 
valuation: the cartonera publishers are engaged in the ambivalent generation of political value by reference to a lack thereof in terms of recognition and money. In this sense, the fundamental political question seems to me to be: How do we theorise and analyse the mediation of their forms and values of publishing within the context of academic writing about and with them?

Paolo Favero's article links to yet another medium constitutive of and composed by global flows of data: digital art and image-production. He sharply contrasts the technological capacities and aesthetic aspirations of 'emerging image-based immersive practices, techniques and tools' (Favero, this issue) with the collapsing dualisms of modernisms, including those of presence and absence, but also past and present, here and there. By way of an unexpected comparison with the visuality of Byzantine icons, Favero argues, we can detect shared principles of visual immersive art as 'the result of a dialogue across the elsewhere and the "elsewhen"' (Favero, this issue). Icons and immersive digital image-making practices, despite their innumerable differences, inform one another. In particular, he suggests, 'the world of icons' allows us to recognize that the premise of virtual images as transporting mediums into a different sphere, they actually 're-centralize' our relations to the self and surrounding. In that sense, digital technologies of image-making are 'paradoxical' since they are at once recreating a sense of presence while crafting an artificial otherwise, an ambition that, Favero claims, is hardly singular to the contemporary West.

Indeed, visual culture (including earlier technologies with broad circulation, such as photographs) has long been co-constitutive of the production of selves and relations to the then and there. As the author puts it, "[photographs] are held, caressed, stroked, sung: they become sound, the sounds of voices, of songs, of memories verbalised as stories' (Favero, this issue). Not least since Roland Barthes' critique of the analogon metaphor (1977), photographs, like other forms of visual representation, are exposed for what they are not: transparent windows into the world. Favero takes this into another direction, arguing for a greater attunement of the ways in which images throw us back on ourselves, as it were. After one particularly disjunctive VR experience, during which he (the user) accidentally reached out in front of him to touch a table that was not programmed in the VR experience, he noted the evocative and central question here: 'Should I trust my eyes or my hands?' (Favero, this issue). This throws us, like Barthes' analysis, right into the politics of the digital and the reliance on other media: How are we to theorize the presence of art and aesthetics within the affordances and infrastructures of the media in which we are embedded as ethnographers?

Favero's main point regarding iconic figurative centres (such as an image of Christ) concerns their transformative intention; having as their 'primary vision not that of representing but rather of taking the worshipper elsewhere, to transform them though vision' (Favero, this issue). As such, the question becomes one of conceptualizing a visual frame beyond the viewer's agency. More interestingly, perhaps, it is a methodological question besides a linguistic one, as the author suggests. Borrowing the notion of an 'imaginal' world from Henry Corbin (1971), Favero argues that it might serve as an 'intermediary', bringing together observer and observed, object and subject. 


\section{Conclusion}

(a)

The articles in this special issue cover a broad range of ethnographic sites, ranging from the Off in the contemporary African art biennale of Dakar to auction houses of non-European art in Paris, cartonera publishing in Buenos Aires and digital imageproduction techniques across locales. Yet they all share a concern for a series of overlapping problems, including those two key sets of issues I have discussed under the headings of institutions, histories, and spheres of valuation (Thomas Fillitz and Tamara Schild) and immersion, correspondence, and form (Alex Flynn/ Lucy Bell and Paolo Favero). Across these articles, questions about the role of institutions in articulating scales of global and local are addressed through issues of valuation and demarcation. These contributions speak about the commensurability and interrelation of starkly contrasted spheres of aesthetic valuation and artistic production - many of which include a strong element of trans-anthropological reflexivity.

Notably, the authors share a concern for translations of methodologies that draws on art historical, economic, activist, and visual fields, cognizant of the mobility of forms and methods of research across fields of artistic and scholarly production, but also sites of research and exchange. The papers address furthermore the performativity of institutions as well as methods, analysing closely the different professional roles and characters that emerge and co-constitute each other in these fields. Two major questions, however, remain about the constitutive agency of these figures: How do they - how do we as anthropologists - choreograph such 'aesthetic encounters' ourselves, considering ethnography as a kind of mise-en-scène? And in what ways might these creative reconfigurations of ethnographic designs offer alternative notions and practices into digital and analogue creations and circulations of aesthetic experiences and social forms? This last point concerns a term coined by Sherry B. Ortner in Not Hollywood (2013), namely 'interface ethnography'. Evoking the question of the intersection between public infrastructures of circulation (auction house publicity, biennale catalogues, or cartoneras) and anthropological scholarship, it remains to be seen, how future research organizes and makes sense of the fact that the fields we study are themselves providing theatrical settings for anthropology, rather than passively welcoming our attention. I propose to consider the sites of global articulation presented in this exciting collection themselves as reflexive trans-anthropological experiments, which leave an anachronistic anthropology of contemporary art much to do yet.

\section{BIBLIOGRAPHY}

Agamben, Giorgio. [2008] 2009. What Is the Contemporary?. In What Is an Apparatus? and Other Essays, transl. David Kishik and Stefan Pedatella. Pp. 51-52. Stanford, CA: Stanford University Press. 
Alexander, Catherine and Andrew Sanchez, eds. 2018. Indeterminacy. Waste, Value, and the Imagination. Oxford and New York: Berghahn.

Appadurai, Arjun. 2001. Modernity at Large. Cultural Dimensions of Globalisation. Minneapolis and London: University of Minnesota Press.

Avanessian, Armen. 2017. Miamification. Leipzig: Merve.

Balzer, David. 2015. Curationism. How Curating Took Over the Art World and Everything Else. London: Pluto.

Barthes, Roland. 1977. The Photographic Message. In: Image, Music, Text. Stephen Heath, ed. Pp. 15-31. New York: Hill and Wang.

Bishop, Claire. 2012. Artificial Hells: Participatory Art and the Politics of Spectatorship. London and New York: Verso.

Corbin, Henry. 1971. En Islam iranien: aspects spirituels et philosophiques. Paris: Gallimard.

Dimitrakaki, Angela. 2012. Art, Globalisation and the Exhibition Form. What is the Case, what is the Challenge? Third Text 26(3): 305-319.

Fillitz, Thomas and Paul van der Grijp, eds. 2018. An Anthropology of Contemporary Art: Practices, Markets, and Collectors. London: Bloomsbury Academics.

Flynn, Alex and Jonas Tinius. 2015. Reflecting on Political Performance: Introducing Critical Perspectives. In Anthropology, Theatre, and Performance: The Transformative Potential of Performance. Alex Flynn and Jonas Tinius, eds. Pp. 1-28. Basingstoke: Palgrave Macmillan.

Foucault, Michel. 1986. Of Other Spaces. Diacritics 16: 22-27.

García Canclini, Néstor. 2014a. Imagined Globalization, trans. George Yúdice. Durham and London: Duke University Press.

García Canclini, Néstor. 2014b. Art Beyond Itself: Anthropology for a Society Without a Story Line, trans. David Frye. Durham and London: Duke University Press.

Geismar, Haidy. 2001. What's in a Price? An Ethnography of Tribal Art at Auction. Journal of Material Culture 6(1): 25-47.

Kearney, Michael. 1995. The Local and the Global: The Anthropology of Globalization and Transnationalism. Annual Review of Anthropology 24(1): 547-565.

Kompatsiaris, Panos. 2017. The Politics of Contemporary Art Biennials. Spectacles of Critique, Theory and Art. London and New York: Routledge.

Levine, Caroline. 2015. Forms: Whole, Rhythm, Hierarchy, Network. Princeton and Oxford: Princeton University Press.

Levitt, Peggy. 2015. Artifacts and Allegiances. How Museums put the Nation and the World on Display. Berkeley, Los Angeles, London: University of California Press.

Marcus, George E. and Fred R. Myers. 1995. The Traffic in Art and Culture: An Introduction. In The Traffic in Art and Culture. Refiguring Art and Anthropology. George E. Marcus and Fred R. Myers, eds. Pp. 1-51. Berkeley, Los Angeles, London: University of California Press.

Njami, Simon. 2006. C'était Senghor. Paris: Fayard.

Ortner, Sherry B. 2013. Not Hollywood: Independent Film at the Twilight of the American Dream.

Durham and London: Duke University Press. 
Oswald, Margareta von and Jonas Tinius 2020. Across Anthropology. An Introduction. In Across Anthropology. Troubling Colonial Legacies, Museums, and the Curatorial. Margareta von Oswald and Jonas Tinius, eds. Leuven: Leuven University Press.

Rancière, Jacques. 2004. The Politics of Aesthetics, trans. Gabriel Rockhill. London and New York: Continuum.

Sarr, Felwine and Bénédicte Savoy. 2018. Restituer le Patrimoine Africain. Paris: Philippe Rey/Seuil. http://restitutionreport2018.com/sarr_savoy_en.pdf (accessed March 5, 2019).

Schneider, Arnd. 2015. Towards a New Hermeneutics of Art and Anthropology Collaborations. EthnoScripts 17(1): 23-30.

Schneider, Arnd. 2017. Alternatives: World Ontologies and Dialogues Between Contemporary Arts and Anthropology. In Alternative Art and Anthropology: Global Encounters. Arnd Schneider, ed. Pp. 1-26. London et al.: Bloomsbury Academics.

Ssorin-Chaikov, Nikolai. 2013. Ethnographic Conceptualism: An Introduction. Laboratorium 5(2): $5-18$.

Strathern, Marilyn. 1996. Cutting the Network. The Journal of the Royal Anthropological Institute 2(3): 517-535.

Sylla, Abdou. 1998. Arts Plastiques et Etat au Sénégal: Trente Cinq Ans de Mécénat au Sénégal. Dakar: IFAN-Ch. A. Diop.

Tinius, Jonas. 2018. Awkward Art and Difficult Heritage: Nazi Art Collectors and Postcolonial Archives. In An Anthropology of Contemporary Art: Practices, Markets, and Collectors. Thomas Fillitz and Paul van der Grijp, eds. Pp. 130-145. London et al.: Bloomsbury Academics.

Tinius, Jonas and Sharon Macdonald. 2020. The Recursivity of the Curatorial. In The Anthropologist as Curator. Roger Sansi, ed. Pp. 35-58. London et al.: Bloomsbury Academics.

Tinius, Jonas and Khadija von Zinnenburg. 2020. Phantom palaces: Prussian centralities and Humboldtian spectres. In Re-Centring the City. Global Mutations of Socialist Modernity. Jonathan Bach and Michał Murawski, eds. Pp. 90-103. London: UCL Press.

\section{ABSTRACTS}

Reflecting on two sets of analytical trajectories of the articles in this special issue - 'institutions, histories, and spheres of valuation' (Thomas Fillitz and Tamara Schild) and 'immersion, correspondence, and form' (Alex Flynn/Lucy Bell and Paolo Favero) -, I argue for an attuned anthropology of the contemporary. This latter focuses on the tensions of art and aesthetics across scales of glocality, and might benefit from what I would like to call an anachronistic and anatopical positionality and approach. I thus consider us in a trans-anthropological phase, in which anthropology no longer documents, but constitutes these fields itself. This affords a greater reflexivity about the collaborative modalities and theoretical value generated through our scholarship as anthropologists; it also asks for a recalibrated ethnographic awareness of the co-articulation of art and anthropology at all scales of their encounter.

À partir des deux approches analytiques des articles ici présentés- «institutions, histoires, et sphères de production de valeurs» (Thomas Fillitz and Tamara Schild), ainsi qu' «immersion, correspondance, et forme» (Alex Flynn/Lucy Bell et Paolo Favero) -, j'argumente dans cet épilogue pour une anthropologie de la contemporanéité réceptive. Celle-ci se formerait sur la base des tensions entre art et esthétique à travers différentes échelles de glocalité, et 
bénéficierait d'une approche anachronique et «anatopical». Je conçois donc une période postanthropologique, dans laquelle l'anthropologie ne s'achève plus dans la documentation, mais constitue elle-même ces champs. Ceci requiert une réflexivité avancée à propos des modalités collaboratives et de la valeur théorique qui sont produites au cours de la recherche anthropologique ; ceci demande aussi une conscience ethnographique qui est re-calibrée sur les articulations entre art et anthropologie à tous les niveaux de leur rencontre.

Partiendo de dos aproximaciones analíticas presentes en los artículos de este número especial: 'instituciones, historias y esferas de valoración' (Thomas Fillitz y Tamara Schild) y 'inmersión, correspondencia y forma' (Alex Flynn / Lucy Bell y Paolo Favero ), propongo una antropología "receptiva" o "sintonizada" (attuned) de lo contemporáneo. Ésta se centra en las tensiones entre arte y estética a través de escalas de glocalidad, y podría beneficiarse de lo que me gustaría llamar un enfoque y una posicionalidad anacrónica y ana-tópica. Por lo tanto, considero que nos encontramos en una fase post-antropológica, en la que la antropología ya no documenta sino que constituye estos mismos campos. Esto permite una mayor reflexividad sobre las modalidades colaborativas y sobre el valor teórico generado mediante nuestra labor académica como antropólogos. También exige una conciencia etnográfica que recalibre la co-articulación entre arte y a antropología a todos los niveles.

\section{INDEX}

Mots-clés: institutions, esthétique, arts visuels, art contemporain, anachronisme, échelle, valeur, globalisme

Keywords: institutions, aesthetics, visual art, contemporary art, anachronism, scale, value, globalism

Palabras claves: instituciones, estética, arte visual, arte contemporáneo, anacronismo, escala, valor, globalismo

\section{AUTHOR}

\section{JONAS TINIUS}

Centre for Anthropological Research on Museums and Heritage, Department of European Ethnology, Humboldt zu Universität Berlin

Jonas.tinius@hu-berlin.de 